\title{
ISOLASI OLIGOSAKARIDA MADU LOKAL DAN ANALISIS AKTIVITAS PREBIOTIKNYA
}

(Isolation of Oligosaccharides from Local Honey and Analysis of its Prebiotic Activity)

Umul Karimah $^{1 *}$, Yogi Nur Anggowo ${ }^{1}$, Syamsul Falah ${ }^{1}$, dan Suryani ${ }^{1}$

${ }^{1}$ Departemen Biokimia, Fakultas Matematika dan IImu Pengetahuan Alam, IPB

* Alamat korespondensi: Departemen Biokimia, Fakultas Matematika dan IImu Pengetahuan Alam, Institut Pertanian Bogor, Bogor 16680. Telp: 0251-8323166

\section{ABST RACT}

The objective of this study was to isolate oligosaccharides from local honey of Pulau Sumbawa and province of Kalimantan Timur and to analyze its prebiotic activity in vitro. Oligosaccharides were isolated with activated charcoal adsorption and ethanol treatment. Effectiveness of this method was evaluated by Thin Layer Chromatography and colorimetry. The isolates were then being a sample to prebiotic examination. Honey from Sumbawa forest has higher oligosaccharides content than honey from Kalimantan. Qualitative and quantitative assays showed that oligosaccharide isolation method was effective to concentrate the oligosaccharide with high degree of polymerization but ineffective for mono- and disaccharides removal. The highest percentages of hydrolysis of oligosaccharide from Sumbawa and Kalimantan by mimic gastric juice were $1.78 \%$ and $0.59 \%$ Whereas, the hydrolysis was higher with amylase, $11.87 \%$ for Sumbawa and $21.03 \%$ for Kalimantan honey oligosaccharides. Prebiotic activity was 0.32 , and 0.09 for honey oligosaccharide from Sumbawa and Kalimantan respectively. Honey oligosaccharide from Sumbawa presented higher prebiotic activity than inulin as prebiotic reference $(0.11)$. GCMS chromatogram showed L. acidophilus cultured in media added with Sumbawa honey oligosaccharide produced lactic acid as the highest metabolite (48.01\%).

Key words: oligosaccharide, local honey, prebiotic activity

\section{PENDAHULUAN}

Prebiotik merupakan komposisi pangan yang tidak tercerna dan memberikan keuntungan melalui modulasi mikrobiota (FAO 2007). Prebiotik mampu menstimulasi pertumbuhan mikroflora menguntungkan seperti Lactobacilli dan Bifidobacteria. Beberapa laporan tentang efek prebiotik antara lain efek antipatogenik (Schley \& Field 2002), menurunkan lemak (Anderson \& Gilliland 1999) dan kolesterol (Williams \& J ackson 2002), meningkatkan absorpsi mineral (Scholz-Ahrens et al. 2007), dan mencegah kanker (Reddy et al. 1997). Sumber prebiotik umumnya merupakan oligosakarida, yaitu karbohidrat dengan panjang rantai 3 sampai 10 unit (Roberfroid 2007).

Madu adalah salah satu campuran karbohidrat yang paling rumit di alam (Soga 2002). Kandungan terbesar pada madu adalah fruktosa dan glukosa. Komponen lainnya yaitu oligosakarida (Ruiz-Matute et al. 2010), mineral (Nanda et al. 2003), senyawa fenolik (Yao et al. 2003), enzim, dan air. Oligosakarida dari madu dapat meningkatkan jumlah bakteri feses secara in vitro (Sanz et al. 2005). Vamanu et al. (2008) membuat formulasi produk simbiotik antara bakteri asam laktat sebagai probiotik dengan polen dan madu sebagai sumber prebiotik.

Produksi madu lokal di Indonesia mencapai 115 ton per tahun dengan daya serap sebesar $13 \%$ (Silitonga \& Munthe 2009). Apis dorsata adalah lebah madu yang hidup di hutan Indonesia dan merupakan lebah madu lokal yang paling produktif (Hutagalung 2008). Penelitian ilmiah mengenai madu lokal di Indonesia masih terbatas, termasuk tentang komponen oligosakarida madu lokal serta potensinya sebagai prebiotik. Penelitian ini bertujuan mengisolasi oligosakarida madu lokal dari lebah Apis dorsata asal Pulau Sumbawa dan Provinsi Kalimantan Timur dan menganalisis aktivitas prebiotiknya secara in vitro.

\section{MATERI DAN METODE}

\section{Bahan dan Alat}

Sampel madu berasal dari Hutan Bukit Gunung Tambora, Kab. Bima, Provinsi Nusa Tenggara Barat, dan Hutan Kampung Bluan Kab. Kutai Barat, Provinsi Kalimantan Timur. Sampel diperoleh pada bulan Februari 2010. Bahan yang digunakan adalah arang aktif, 
etanol, kertas saring Whatman No.1, lempeng KLT K6F silika 250 $\mathrm{m}$ (Merck), piridin, butanol, $\mathrm{N} *(1-n a f t i l)$ etilendiamina dihidroklorida (Merck), metanol, $\mathrm{H}_{2} \mathrm{SO}_{4}$, glukosa, fruktosa, dan maltosa, asam lambung buatan, $\mathrm{HCl}$, reagen Dinitrosalisilat (DNS), fenol, saliva, bufer Na-fosfat, isolat Lactobacillus acidophilus (koleksi Laboratorium Mikrobiologi, Pusat Antar Universitas, PAU, IPB), kultur Escherichia coli, kaldu de Mann Rogosa Sharpe (MRS Broth, MRSB) (Oxoid), Nutrient Broth (NB) (Oxoid), kaldu media Minimal M9 (MM9), inulin chicory (Merck).

Alat yang digunakan dalam penelitian ini adalah oven, neraca analitik OHAUS GA 200, vakum, hot plate stirrer (Gerhardt), inkubator (Kottermann Wisebath), penangas air, spektrofotometer Genesys 10UV, laminar, otoklaf TOMY High Pressure Steam Sterilizer ES-315, GC-MS pirolisis Shimadzu (Pusat Penelitian dan Pengembangan Departemen Kehutanan).

\section{Metode}

Penelitian ini diawali dengan isolasi oligosakarida madu lokal. Isolat kemudian diuji secara kualitatif dan kuantitatif untuk mengetahui kandungan karbohidrat. Selain itu, diuj i pula tiga kriteria prebiotik dari isolat, yaitu resistensi terhadap hidrolisis asam lambung dan a-amilase, stimulasi pertumbuhan bakteri, dan aktivitas fermentasi bakteri.

Isolasi Oligosakarida (Hernandez et al. 2009)

Sebanyak 500 mg madu ditambah dengan 3 gram arang aktif kemudian dilarutkan ke dalam $100 \mathrm{~mL}$ etanol 10 persen dan diaduk selama 30 menit. Campuran disaring dengan kertas saring Whatman No.1 pada keadaan vakum dan arang aktif dibilas dengan $25 \mathrm{~mL}$ etanol 10 persen. Desorpsi oligosakarida dilakukan dengan menambahkan $100 \mathrm{~mL}$ etanol 50 persen v/v. Campuran diaduk selama 30 menit dan disaring lagi dengan kertas saring Whatman No.1. Filtrat dievaporasi pada keadaan vakum pada suhu $40^{\circ} \mathrm{C}$.

Deteksi Oligosakarida dengan Kromatografi Lapis Tipis (KLT)

Efektivitas metode isolasi oligosakarida diuji secara kualitatif dengan KLT. Sampel dilarutkan dalam etanol 50 persen dengan konsentrasi 5 persen b/ v, standar karbohidrat dibuat pada konsentrasi 1 persen b/v. Sampel ditotolkan ke lempeng KLT dan dielusi dengan campuran pelarut piridin:butanol:air (4:6:3 v/ v) (Aso et al. 1960). Setelah kering, lempeng direndam hingga jenuh dengan larutan berisi $0.3 \mathrm{~g} / 100 \mathrm{~mL} \quad \mathrm{~N} *(1-n a f t i l)$ etilendiamina dihidroklorida pada sistem pelarut yang terdiri atas metanol: $\mathrm{H}_{2} \mathrm{SO}_{4}$ (97:3 v/ v) (Vergara et al. 2010). Lempeng dipanaskan pada oven dengan suhu $90^{\circ} \mathrm{C}$ hingga spot dapat terlihat.

\section{Pengukuran Komposisi Karbohidrat}

Gula pereduksi diukur dengan metode DNS (modifikasi Wichienchot et al. 2010). Karbo-hidrat total diukur dengan metode fenol-sulfat (modifikasi Wichienchot et al. 2010). Kurva standar glukosa dibuat pada konsentrasi $0-1 \mathrm{mg} / \mathrm{mL}$.

\section{Pengujian Kriteria Prebiotik}

Resistensi terhadap hidrolisis asam lambung (Wichienchot et al. 2010)

Isolat oligosakarida dilarutkan dalam air reverse osmosis (RO) dengan konsentrasi 1 $\mathrm{mg} / \mathrm{mL}$. Asam lambung buatan dibuat dengan buffer $\mathrm{HCl}$ dengan komposisi dalam $\mathrm{g} / \mathrm{L}: \mathrm{NaCl}$ (8), $\mathrm{KCl}(0.2), \mathrm{Na}_{2} \mathrm{HPO}_{4} \cdot 2 \mathrm{H}_{2} \mathrm{O}$ (8.25), $\mathrm{NaH}_{2} \mathrm{PO}_{4}$ (14.35), $\mathrm{CaCl}_{2} \cdot 2 \mathrm{H}_{2} \mathrm{O}(0.01), \mathrm{MgCl}_{2} \cdot 6 \mathrm{H}_{2} \mathrm{O}(0.18)$. Pengaturan $\mathrm{pH} 2$ dilakukan dengan $\mathrm{HCl} 5 \mathrm{M}$. Buffer $\mathrm{HCl}$ ditambahkan ke larutan sampel dengan perbandingan 1:1 dan diinkubasi pada suhu $37^{\circ} \mathrm{C}$ selama 2 jam. Pada jam ke- 0,1 , dan 2 diambil $0.2 \mathrm{~mL}$ untuk pengujian kandungan gula pereduksi, sementara itu untuk pengukuran karbohidrat total diambil sebanyak 0.2 $\mathrm{mL}$ dan hanya diukur pada jam ke-0. Pengujian dilakukan dengan dua kali ulangan. Persentase hidrolisis dihitung dengan rumus sebagai berikut:

$$
\text { Hidrolisis }(\%)=\frac{G p_{t}-G p_{0}}{\left(\text { total } K H-G p_{0}\right)} \times 100
$$

\section{Keterangan}

$\mathrm{Gp}_{\mathrm{t}}=$ konsentrasi gula pereduksi jam ke-t

$\mathrm{Gp}_{0}=$ konsentrasi gula pereduksi jam ke-0

$\mathrm{KH}=$ konsentrasi karbohidrat

Resistensi terhadap hidrolisis a-amilase (Wichienchot et al. 2010).

Amilase diperoleh dari saliva yang diencerkan hingga konsentrasinya 3 unit/ $\mathrm{mL}$. Isolat oligosakarida disiapkan dengan membuat larutan 1 persen sampel pada bufer Na-fosfat. Kemudian Iarutan enzim ditambahkan ke larutan sampel dengan perbandingan 1:1. Campuran diinkubasi selama 4 jam dan diukur gula pereduksinya pada jam ke-0, 1, 2, dan 4. Langkah lainnya sesuai dengan pengujian resistensi terhadap hidrolisis asam lambung. 
Stimulasi pertumbuhan bakteri (modifikasi Huebner et al. 2008)

Bakteri yang digunakan adalah bakteri probiotik L. acidophilus dan bakteri enterik $\mathrm{E}$. coli. Sebelum digunakan, kultur L. acidophilus ditumbuhkan pada MRSB semalam pada suhu $37^{\circ} \mathrm{C}$ secara aerob dengan aerasi $100 \mathrm{rpm}$. Kultur E. coli diperlakukan sama dengan perbedaan media kultur yaitu NB. Media uj i stimulasi terdiri atas $10 \mathrm{~mL}$ MRSB untuk bakteri probiotik dan media MM9 untuk bakteri enterik. Setiap media ditambah dengan $1 \mathrm{~mL}$ Iarutan berisi $10 \mathrm{mg}$ sampel. Kultur bakteri kemudian diinokulasi sebanyak 5 persen $\mathrm{v} / \mathrm{v}$ ke dalam media uji stimulasi dan diinkubasi selama 24 jam pada suhu $37^{\circ} \mathrm{C}$ dengan aerasi. Rapat Optik (Optical Density, OD) diukur pada $\lambda 600 \mathrm{~nm}$ pada jam ke-0, dan 24. Blanko adalah media uji stimulasi tanpa inokulasi bakteri. Aktivitas stimulasi dinyatakan secara kuantitatif melalui

$$
\left[\frac{P p t-P p 0}{P g t-P g 0}\right]-\left[\frac{E p t-E p 0}{E g t-E g 0}\right]
$$

Keterangan:

Ppt $=$ OD probiotik pada prebiotik setelah $\mathrm{t}$ jam

Pp0 = OD probiotik pada prebiotik setelah 0 jam

Pgt $=O D$ probiotik pada kontrol (glukosa) setelah t jam

Pg0 = OD probiotik pada kontrol (glukosa) setelah 0 jam

Ept $=O D$ enterik pada prebiotik setelah $\mathrm{t}$ jam

Ep0 =OD enterik pada prebiotik setelah 0 jam

Egt $=O D$ enterik pada kontrol (glukosa) setelah $t$ jam

Eg0 = OD enterik pada kontrol (glukosa) setelah 0 jam

\section{Aktivitas Fermentasi Bakteri}

Kultur L. acidophilus yang menunjukkan efek stimulasi pertumbuhan tertinggi diuj $i$ untuk aktivitas fermentasi bakteri. Aktivitas kultur ditentukan dengan mengukur produk akhir fermentasi yang berupa asam organik dengan GC-MS Pirolisis Shimadzu. Suhu injektor $200^{\circ} \mathrm{C}$, helium sebagai gas pembawa, dan Flame Ionization Detector (FID) sebagai detektor. Kromatogram yang diperoleh dibandingkan dengan basis data Wiley7.

\section{HASIL DAN PEMBAHASAN}

\section{Karakteristik Warna dan Isolat Oligosakarida Madu}

Hutan Sumbawa dan Kalimantan merupakan sentra perburuan madu hutan di Indonesia. Sampel madu hutan diambil pada bulan Februari 2010 dengan bantuan penduduk setempat. Madu lokal yang digunakan dihasil- kan dari lebah hutan Apis dorsata. Kedua sampel madu yang digunakan adalah madu multifloral.

Madu lokal Sumbawa memiliki warna coklat keruh, sementara madu Kalimantan berwarna coklat bening. Aso et al. (1960) menyebutkan beberapa warna madu antara lain kuning, kuning pucat, coklat, coklat pucat, dan coklat gelap. Faktor utama yang menyebabkan perbedaan warna pada madu adalah sumber nektar (National Honey Board). Faktor lain yang mempengaruhi warna madu adalah proses penyimpanan, kadar senyawa fenolik, dan kadar mineral (Anklam 1997).

Rendemen isolat oligosakarida madu Sumbawa adalah 1.79 persen, sedangkan rendemen isolah madu Kalimantan sebesar 2.06 persen. Isolat yang dihasilkan berwarna hitam untuk madu Sumbawa dan coklat untuk madu Kalimantan. Hal ini terkait dengan warna madu sebelum isolasi. Kedua isolat yang diperoleh terlihat mengilap yang diduga merupakan gula yang mengalami karamelisasi.

\section{Kromatogram Oligosakarida Madu Sumbawa dan Kalimantan}

Kromatogram yang dihasilkan menunjukkan kandungan madu dan isolat oligosakarida madu Sumbawa relatif sama yakni monosakarida campuran glukosa dan fruktosa, dan karbohidrat dengan QR (Gambar 1a).

Terdapat sedikit perbedaan nilai Rf yang diduga berasal dari matriks sampel yang mempengaruhi pergerakan karbohidrat selama proses elusi.

Spot kromatogram isolat oligosakarida dengan nilai $\operatorname{Rf} 0.46,0.56$, dan 0.68 memiliki ketebalan yang hampir sama dengan spot pada madu Sumbawa. Ini mengindikasikan bahwa tahap isolasi tidak begitu mempengaruhi jumlah karbohidrat tersebut. Spot untuk di- dan monosakarida yang tebal menunjukkan kandungan keduanya masih tinggi. Hal ini memperkuat hasil yang diperoleh pada visualisasi isolat oligosakarida yang mengkilap.

Kromatogram isolat oligosakarida juga menunjukkan 2 spot baru dengan $\mathrm{Rf} 0.12$ dan 0.46 yang dapat dibedakan menjadi spot secara jelas dan diduga merupakan oligosakarida yang paling banyak dikandung oleh madu Sumbawa. Selain itu di antara kedua spot terdapat ekor yang menunjukkan kumpulan oligosakarida. Ekor tersebut tidak dapat dibedakan secara jelas menjadi spot-spot tertentu. Hal ini dikarenakan pada madu terdapat puluhan jenis senyawa karbohidrat dengan kadar 
yang rendah sehingga tidak memberikan batas antarspot yang spesifik.

Kromatogram madu Kalimantan menghasilkan empat spot sementara isolat oligosakaridanya menghasilkan lima spot (Gambar 1b). Kromatogram isolat menunjukkan komposisi karbohidrat yang relatif sama dengan madu tanpa isolasi yakni mono-, disakarida, dan karbohidrat $D \& 2$. Jika dibandingkan dengan nilai Rf standar, spot dengan nilai Rf 0.69 diduga sebenarnya terdiri atas dua spot yaitu mono- dan disakarida. Spot ini jauh lebih tebal dibandingkan spot Iain. Oleh karenanya isolat oligosakarida madu Kalimantan juga diperkirakan masih mengandung mono- dan disakarida yang tinggi. Terdapat dua spot oligosakarida dengan nilai Rf 0.11 dan 0.37. Kedua spot ini hanya muncul pada kromatogram isolat oligosakarida. Isolat oligosakarida madu Kalimantan juga menunjukkan adanya ekor pada kromatogram yang mengindikasikan beragam karbohidrat dalam jumlah yang rendah (Gambar 1b).

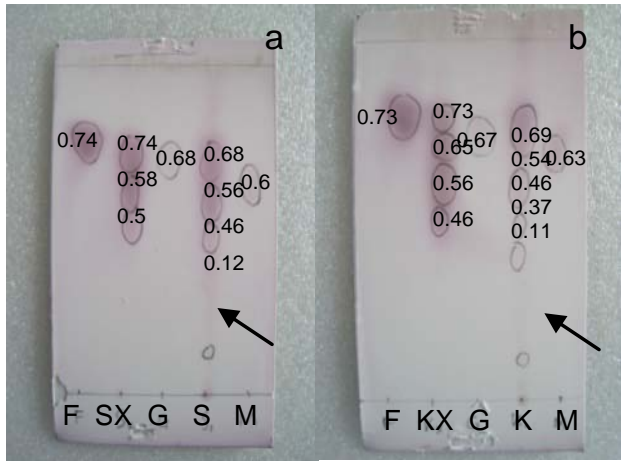

Gambar 1. Kromatogram Isolat Oligosakarida Madu (a) Sumbawa; (b) Kalimantan. F: fruktosa, G: glukosa, M: Maltosa, SX: madu Sumbawa, $S$ : isolat oligosakarida madu Sumbawa, KX: madu Kalimantan, K: isolat oligosakarida madu Kalimantan. Ekor kromatogram ditunjukkan dengan tanda panah.

Kromatogram isolat oligosakarida madu Sumbawa dan Kalimantan menunjukkan metode isolasi oligosakarida yang digunakan efektif dalam memekatkan kadar karbohidrat dengan DP yang lebih tinggi (DP3). Ini dapat dilihat dari sampel isolat oligosakarida yang menunjukkan adanya spot-spot baru. Hasil kromatogram isolat oligosakarida madu Sumbawa dan Kalimantan juga menunjukkan adanya ekor pada kromatogram. Hal ini menandakan bahwa pada konsentrasi dan penotolan sampel KLT yang sama, oligosakarida pada madu berada pada kadar yang sangat rendah sehingga tidak dapat dideteksi dan menghasilkan spot. Sementara itu proses isolasi mampu meningkatkan kadar oligosakarida sehingga dapat terlihat pada kromatogram meskipun belum dapat digolongkan menjadi spot yang spesifik. Masih adanya spot mono- dan disakarida menandakan senyawa-senyawa tersebut belum berhasil dihilangkan dan masih berada dalam jumlah yang tinggi.

\section{Komposisi Karbohidrat Madu Hasil Isolasi}

Kandungan karbohidrat isolat oligosakarida madu juga ditentukan secara kuantitatif dengan metode spektrofotometri. Madu Sumbawa mengandung gula pereduksi $36.24 \pm 0.24$ persen dan karbohidrat total $66.02 \pm 0.54$ persen b/b. Adapun isolat oligo-sakarida madu Sumbawa mengandung gula pereduksi dan karbohidrat total berturut-turut $33.59 \pm 0.66$ dan $64.38 \pm 2.99$ persen b/b. Madu Kalimantan mengandung gula pereduksi $67.8 \pm 0.38$ persen dan karbohidrat total $82.45 \pm 3.7$ persen $b / b$. Sementara itu isolat oligosakaridanya mengandung gula pereduksi $42.39 \pm 1.19$ persen dan karbohidrat total 73.99+2.55 persen b/ b.

Menurut Khalil et al. (2001), kandungan gula pereduksi madu sekitar 75 persen, dan karbohidrat totalnya mencapai 85 persen. Madu Sumbawa mengandung gula pereduksi dan karbohidrat total yang lebih rendah. Sementara itu, madu Kalimantan mengandung gula pereduksi dan karbohidrat total dalam rentang umum tersebut. Namun demikian, madu Sumbawa mengandung lebih banyak oligosakarida dibandingkan madu Kalimantan. Kandungan oligosakarida ini dapat dilihat dari selisih antara karbohidrat total dengan gula pereduksinya. Oligosakarida tergolong gula nonpereduksi. Beberapa disakarida juga merupakan gula nonpereduksi. Kandungan oligosakarida madu Sumbawa sekitar 29.78 persen, sementara oligosakarida madu Kalimantan sekitar 14.65 persen.

Uji kuantitatif menunjukkan metode adsorpsi arang aktif dan konsentrasi etanol bertingkat hampir tidak memberi pengaruh pada madu Sumbawa. Kandungan gula pereduksi isolat oligosakarida yang masih tinggi ini memperkuat hasil visualisasi dan kromatogram isolat.

Metode isolasi menurunkan kadar gula pereduksi hingga 25 persen pada isolat oligosakarida madu Kalimantan, sementara karbohidrat total hanya berkurang sedikit. Berdasarkan kromatogramnya, isolat oligosakarida madu Kalimantan menunjukkan spot 
mono- dan disakarida yang masih tebal. Sementara itu metode kolorimetri menunjukkan kandungan gula pereduksinya sudah jauh berkurang dari kandungan madu awal. Hal ini dapat terjadi karena tidak semua disakarida adalah gula pereduksi, sehingga pada pengujian KLT terdeteksi sebagai disakarida tetapi pada kolorimetri tidak terdeteksi sebagai gula pereduksi.

Hernandez et al. (2009) dan Sanz et al. (2005) menyebutkan mono- dan disakarida dapat dihilangkan hampir seluruhnya dengan metode adsorpsi arang aktif. Hal ini berbeda dengan hasil yang diperoleh baik dengan pengujian kualitatif maupun kuantitatif. Perbedaan hasil yang diperoleh ini dapat disebabkan perbedaan grade bahan isolasi yang digunakan.

\section{Resistensi terhadap Asam Lambung dan Amilase}

Resistensi terhadap asam lambung dan amilase adalah salah satu syarat dari prebiotik (Roberfroid 2007). Sampel menunjukkan persentase hidrolisis isolat oligosakarida madu Sumbawa dan madu Kalimantan berbeda. Keduanya memiliki tingkat hidrolisis asam lambung tertinggi pada jam pertama inkubasi yakni 1.78 persen untuk isolat oligosakarida madu Sumbawa dan 0.59 persen untuk madu Kalimantan. Jumlah ini kemudian menurun pada jam kedua yaitu 1.27 persen untuk isolat oligosakarida madu Sumbawa dan -0.4 persen untuk madu Kalimantan.

Pengukuran pada jam ke-2 menunjukkan persentase hidrolisis bernilai negatif untuk isolat oligosakarida madu Kalimantan. Nilai negatif ini dapat disebabkan adanya gangguan ion dari garam yang menyusun asam lambung buatan. Metode DNS yang digunakan untuk mengukur gula pereduksi akan terganggu bila sampel mengandung banyak ion (Sinegani \& Emtiazi 2006).

Hidrolisis amilase saliva meningkat seiring waktu untuk masing-masing isolat oligosakarida madu. Isolat oligosakarida madu Sumbawa mengalami hidrolisis sebanyak 8.18 , 10.92, dan 11.87 persen pada jam ke-1, 2, dan 4. Sementara isolat oligosakarida madu Kalimantan mengalami hidrolisis sebesar 13.76, 16.12, dan 21.03 persen. Berbeda dengan pengujian resistensi terhadap asam lambung, isolat oligosakarida madu Kalimantan mengalami tingkat hidrolisis yang lebih tinggi. Hal ini dapat dikaitkan dengan hasil pengukuran komposisi karbohidrat sebelumnya yang menunjuk- kan jumlah gula pereduksi pada isolat oligosakarida madu Kalimantan yang lebih tinggi dibandingkan madu Sumbawa. Resistensi oligosakarida ini sesuai dengan Rittig (2001) dalam Sanz et al. (2005) yang menyebutkan bahwa oligosakarida madu memiliki resistensi terhadap asam lambung dan enzim pencernaan secara in vitro.

\section{Stimulasi Pertumbuhan Bakteri}

Kurva pertumbuhan L. acidophilus yang ditumbuhkan dalam MRSB menunjukkan kultur usia 24 jam telah berada di fase stationer (Gambar 2). Kurva pertumbuhan E. coli berpedoman pada Kao et al. (2004) dan Kaur \& Chakraborti (2010) yang menyebutkan pada jam ke-24, kultur E. coli telah berada pada fase stasioner. Fase stasioner terjadi saat sumber nutrisi yang berasal dari media mulai habis. Uji stimulasi dilakukan dengan memberikan isolat oligosakarida sebagai sumber karbon (C) tambahan ke dalam media kultur bakteri. Bakteri yang mampu memanfaatkan sampel isolat oligosakarida madu sebagai sumber karbonnya akan menunjukkan pertumbuhan yang lebih baik dibandingkan kultur bakteri lainnya. Hal ini ditunjukkan melalui selisih nilai OD antara jam ke-24 dan jam ke-0 yang lebih tinggi.

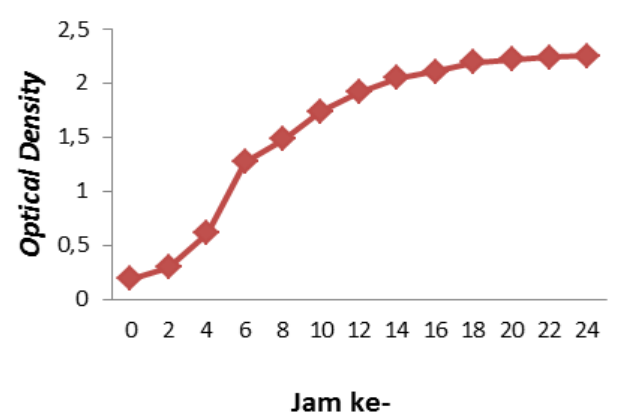

Gambar 2. Kurva Pertumbuhan Lactobacillus acidophilus dalam MRSB

Berdasarkan OD yang diperoleh pada jam ke-0 dan ke-24, diperoleh bahwa isolat oligosakarida madu Sumbawa, Kalimantan, dan inulin memiliki aktivitas prebiotik yaitu mampu menstimulasi pertumbuhan bakteri L. acidophilus. Isolat oligosakarida madu Sumbawa memberikan pengaruh prebiotik sebesar 0.3274, yang hampir tiga kali lebih besar dibanding inulin yakni sebesar 0.1189 , Sementara isolat oligosakarida madu Kalimantan menunjukkan kemampuan stimulasi yang paling rendah yakni 0.0973 .

L.acidophilus diduga memiliki enzim yang mampu mendegradasi oligosakarida madu dan memanfaatkannya sebagai sumber karbon. L. acidophilus memiliki gen msm dan BfrA yang 
terlibat dalam pemanfaatan FOS, salah satu jenis prebiotik, sebagai sumber karbon. Gen msm mengodekan ATP binding cassette (ABC) transporter yang menyalurkan sumber karbon ke dalam sel. Sementara itu gen BfrA mengodekan fruktosidase yang berfungsi untuk mencerna FOS. Efek stimulasi pertumbuhan yang ditunjukkan oleh prebiotik bersifat spesifik terhadap galur bakteri. Tidak semua bakteri probiotik dapat memanfaatkan semua prebiotik (Artanti 2009).

Isolat oligosakarida madu Sumbawa menunjukkan aktivitas prebiotik yang lebih tinggi dibandingkan inulin Biedrzycka dan Bielecka (2004) menyebutkan oligosakarida rantai pendek, tanpa percabangan, dan larut air lebih mudah dimanfaatkan oleh bakteri. Oligosakarida madu umumnya merupakan di-, tri-, dan tetrasakarida, sementara inulin adalah oligosakarida dengan DP 10-60.

\section{Aktivitas Fermentasi}

Kriteria prebiotik ketiga ialah mempengaruhi aktivitas fermentasi. Aktivitas fermentasi diukur melalui produk fermentasi yang dihasilkan kultur. Isolat oligosakarida madu Sumbawa menunjukkan efek stimulasi pertumbuhan yang paling tinggi sehingga kultur $L$. acidophilus yang ditumbuhkan pada media tersebut diuji untuk mengetahui produk fermentasi yang dihasilkan. Kromatogram menunjukkan 19 puncak senyawa terdeteksi dari kultur tersebut (Gambar 3).

Kultur bakteri usia 24 jam yang ditumbuhkan dalam lingkungan aerob menghasilkan asam laktat (puncak E) sebagai metabolit utama yaitu 48.01 persen. L. acidophilus tergolong bakteri asam laktat homofermentatif sehingga metabolit utamanya adalah asam laktat. Berdasarkan kromatogram, asam laktat yang dibentuk seluruhnya merupakan tipe $L(+)$. Hasil ini berbeda dengan Sanders dan Klaenhammer (2001) yang menyebutkan bahwa $\mathrm{L}$. acidophilus menghasilkan asam laktat tipe $L(+)$ dan $D(-)$.

Dalam lingkungan aerob, L. acidophilus menghasilkan asam laktat sebagai metabolit utama, namun dalam keadaan anaerob seperti pada kolon, bakteri ini juga menghasilkan asam asetat yang merupakan asam lemak rantai pendek (Naaber et al. 2004). Asam asetat juga mungkin terbentuk karena asam laktat digunakan oleh bakteri heterofermentatif. Gibson et al. (1996) menyebutkan bahwa dalam kolon, metabolit yang dihasilkan suatu jenis bakteri dapat digunakan oleh bakteri lain dan menghasilkan metabolit yang baru. Jiang dan Savaiano (1997) menyebutkan bahwa penambahan L. acidophilus pada fermentasi kultur berkesinambungan yang diinokulasi dengan bakteri feces menghasilkan peningkatan produksi asam asetat. Asam laktat adalah asam organik yang menguntungkan pada pencernaan karena dapat berfungsi sebagai antimikrob bagi bakteri di dalam kolon (Sanders \& Klaenhammer 2001). Selain itu, salah satu mekanisme penurunan kolesterol oleh L. acidophilus adalah pengikatan kolesterol dengan asam laktat (Suzuki et al. 1991 dalam J iang \& Savaiano 1997).

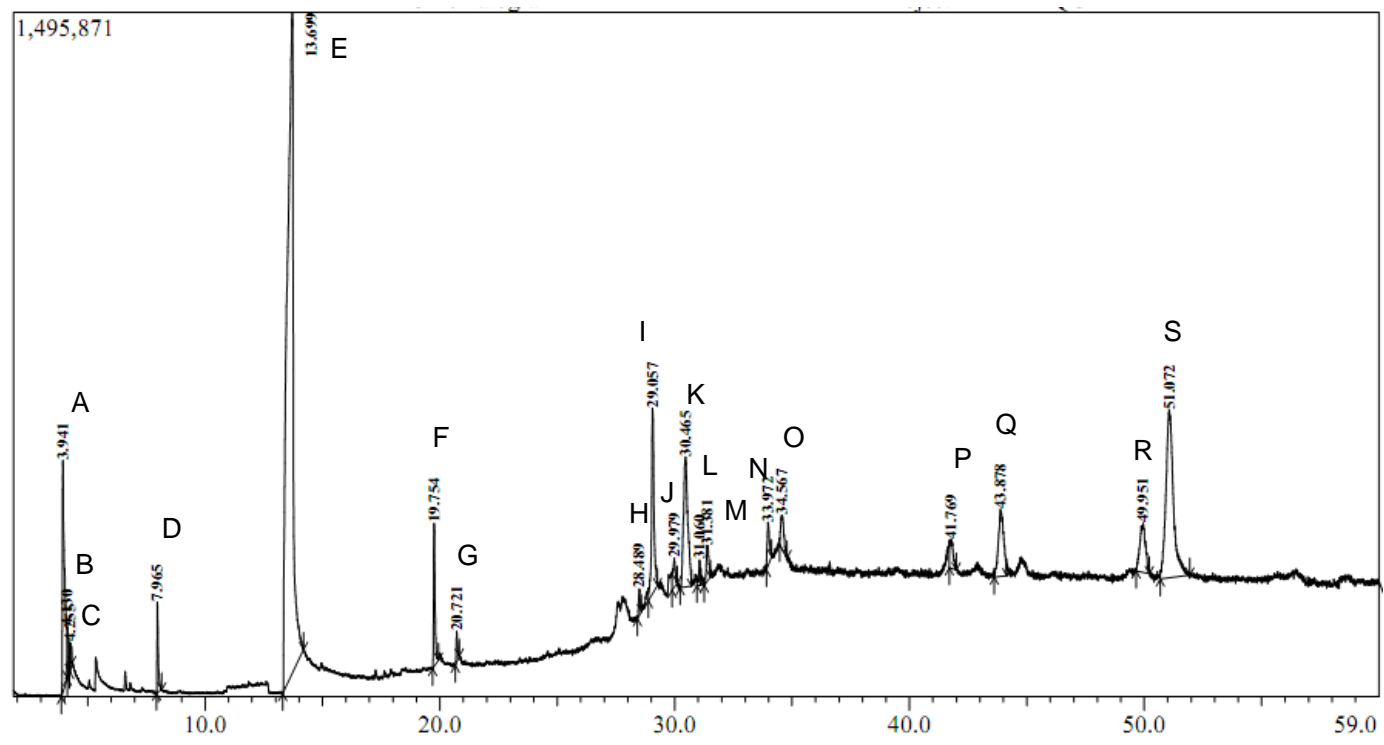

Gambar 3. Kromatogram GC-MS Pirolisis Kultur L. acidophilus dalam MRSB dengan Isolat Oligosakarida Madu Sumbawa sebagai Tambahan Sumber Karbon Menunjukkan Asam Laktat (E) sebagai Metabolit Ekstraseluler yang Utama 



\section{KESIMPULAN}

Madu Sumbawa mengandung jumlah oligosakarida yang lebih tinggi dibandingkan madu Kalimantan. Isolasi oligosakarida dengan arang aktif dan etanol bertingkat 10 dan $50 \%$ tidak efektif untuk menghilangkan mono- dan disakarida tetapi efektif untuk memekatkan konsentrasi oligosakarida $\mathrm{DP} \geq 3$.

Pengujian in vitro menunjukkan isolat oligosakarida madu Sumbawa dan Kalimantan memenuhi kriteria prebiotik yakni resisten terhadap asam lambung dan enzim pencernaan, memiliki efek stimulasi pertumbuhan yang selektif, dan mempengaruhi aktivitas fermentasi. Isolat oligosakarida madu Sumbawa menunjukkan efek stimulasi pertumbuhan bakteri L. acidophilus terbesar. Kultur L. acidophilus yang ditumbuhkan pada media dengan isolat oligosakarida madu Sumbawa sebagai tambahan sumber $\mathrm{C}$ menghasilkan asam laktat sebagai metabolit utama (48.01\%)

Selain itu pemanfaatan potensi ekonomi juga perlu dioptimalkan untuk meningkatkan PDRB/kapita dan dilakukan pendistribusian yang merata agar pembangunan pangan dapat dirasakan oleh semua pihak.

Perlu dilakukan penentuan konsentrasi etanol yang optimum untuk menghilangkan mono- dan disakarida madu. Oligosakarida madu lokal perlu diidentifikasi lebih lanjut. Uji stimulasi pertumbuhan bakteri perlu dilakukan dalam keadaan anaerob sesuai keadaan in vivo pada kolon, dengan isolat berupa campuran bakteri kolon dan fruktooligosakarida (FOS) sebagai prebiotik pembanding.

\section{UCAPAN TERIMA KASIH}

Terimakasih kepada Direktorat J enderal Pendidikan Tinggi (Ditjen Dikti) yang telah mendanai Program Kreativitas Mahasiswa (PKM) Penelitian ini.

\section{DAFTAR PUSTAKA}

Anderson JW \& Gilliland SE. 1999. Effect of fermented milk (yogurt) containing Lactobacillus acidophilus L1 on serum cholesterol in hypercholesterolemic humans. J Am Col Nutrition, 18(1), 4350.

Anklam E. 1997. A review of the analyitical methods to determine the geographical and botanical origin of honey. Food Chem, 63(4), 549-562.

Artanti A. 2009. Pengaruh Prebiotik Inulin dan Fruktooligosakarida (FOS) Terhadap Pertumbuhan Tiga Jenis Probiotik. Skripsi Sarjana Departemen IImu dan Teknologi Pangan, Fakultas Teknologi Pertanian, IPB, Bogor.

Aso K, Watanabe T \& Yamao K. 1960. Studies on honey: on the sugar composition of honey. Tohoku Journal of Agriculture Research, 1, 101-108.

Biedrzycka \& Bielecka M. 2004. Prebiotic effectiveness of fructans different degrees polymerization. Trends in Food Sci \& Tech, 15, 170-175.

[FAO] Food Agriculture Organization. 2007. FAO Technical Meeting on Prebiotics. FAO, Rome.

Gibson GR, Willems A, Reading S, \& Collins MD. 1996. Fermentation of non-digestible oligosaccharides by human colonic bacteria. Proceedings of the Nutrition Society, 55, 899-912.

Hernandez O, Ruiz-Matute Al, Olano A, Moreno FJ \& Sanz ML. 2009. Comparison of fractionation techniques to obtain prebiotic galactooligosaccharides. Int Dairy J, 19, 531-536.

Huebner J, Wehling RL, Parkhurst A \& Hutkins RW. 2008. Effect of processing conditions on the prebiotic activity of commercial prebiotics. Int Dairy J, 18, 287-293.

Hutagalung LE. 2008. Perkembangan Perolehan Madu Lebah Hutan (Apis dorsata) oleh Pemanen Madu di Kabupaten Tapanuli Utara. Skripsi Sarjana Departemen Teknologi Hasil Hutan, Fakultas Kehutanan, IPB, Bogor.

Jiang T \& Savaiano DA. 1997. In vitro lactose fermentation by human colonic bacteria is modified by Lactobacillus acidophilus supplementation. J Nut, 127, 14891495.

Kao et al. 2003. Transcriptome-based determination of multiple transcription regulator activities in Escherichia coli by using network component analysis. PNAS, 101, 641-646. 
Kaur P \& Chakraborti A. 2010. Proteome analysis of food borne pathogen enteroaggregative Escherichia coli under acid stress. J Proteomics Bioinform, 3, 10-19.

Khalil et al. 2001. Biochemical analysis of different brands of unifloral honey available at the northern region of Bangladesh. The Sciences, 1(6), 385388.

Naaber et al. 2004. Inhibition of Clostridium difficile strains by intestinal Lactobacillus species. J Med Microbiol, 53, 551-554.

Nanda et al. 2003. Physico-chemical properties and estimation of mineral content in honey produced from different plants in Northern India. Journal of Food Composition and Analysis, 16, 613-619.

[NHB] National Honey Board. Honey color. www.nhb.org (4 Nov 2010).

Reddy BS, Hamid R, \& Rao CV. 1997. Effect of dietary oligofructose and inulin on colonic preneoplastic aberrant crypt foci inhibition. Carcinogenesis, 18(7), 1371-1374.

Roberfroid M. 2007. Prebiotics: the concept revisited. J Nut, 137, 830-837.

Ruiz-Matute Al, Brokl M, Soria AC, Sanz ML, \& Matinez-Castro. 2010. Gas chromatographic-mass spectrometric characterisation of tri- and tetrasaccharides in honey. Food Chem, 120, 637-642.

Sanders ME \& Klaenhammer TR. 2001. Invited review: the scientific basis of Lactobacillus acidophilus NCFM functionality as a probiotic. J Dairy Sci, 84(2), 319-331.

Sanz et al. 2005. In vitro investigation into the potential prebiotic activity of honey oligosaccharides. J Agric Food Chem, 53(8), 2914-2921.
Schley PD \& Field CJ. 2002. The immuneenhancing effects of dietary fibres and prebiotics. British J Nutr, 87, 221-230.

Scholz-Ahrens et al. 2007. Prebiotics, probiotics, and synbiotics affect mineral absorption, bone mineral content, and bone structure. J Nutr, 137, 838-846.

Silitonga LT \& Munthe MG. 2009. Amway jajaki madu RI masuk pasar dunia. Bisnis Indonesia, 11 September.

Sinegani AAS \& Emtiazi G. 2006. The relative effects of some elements on the DNS method in cellulose assay. J Appl Sci Environ, 10(3), 93-96.

Soga T. 2002. Analysis of carbohydrates in food and bevarages by HPLC and CE. J Chromatogr Library, 66, 483-502.

Vamanu et al. 2008. Obtaining of a symbiotics product based on lactic acid bacteria, pollen and honey. Pakistan J Biol Sci, 11(4), 613-617.

Vergara CMAC, Honorato TL, Maia GA, \& Rodrigues S. 2010. Prebiotic effect of fermented cashew apple (Anacardium occidentale L) juice. Food Sci Tech, 43, 141-145.

Wichienchot S, Jatupornpipat $M, \&$ Rastall RA. 2010. Oligosaccharides of pitaya (dragon fruit) flesh and their prebiotic properties. Food Chem, 120, 850-857.

Williams CM \& Jackson KG. 2002. Inulin and oligofructose: effects on lipid metabolism from human studies. British J Nutr, 87, 261-264.

Yao et al. 2003. Flavonoids, phenolic acids and abscisic acid in Australian and New Zealand Leptospermum honeys. Food Chem, 81, 159-168. 